\title{
PERAN PEREMPUAN DALAM MEWUJUDKAN KELUARGA SEJAHTERA MENURUT PERSPEKTIF EKONOMI ISLAM(STUDI KASUS PEREMPUAN PEDAGANG KAKI LIMA DI SIMPANG TUGU TIGO BALEH, KELURAHAN PAKAN LABUAH, KOTA BUKITTINGGI)
}

\author{
Zuwardi MA
}

IAIN Bukittinggi, Email: zuwardiiyzi84@gmail.com

\begin{abstract}
Along with the development of the times of course the needs of society increase from year to year. Unlimited buman needs, with limited availability of resources. Making women also play a role in meeting the needs of families in an effort to realize a prosperous family. This research was conducted to provide an overview of the role of women in realizing a prosperous family from the perspective of Islamic economics. Research conducted at the Tigo Tigo Baleh Intersection, Pakan Labuah Village, Bukittinggi City uses a qualitative descriptive approach with data obtained from primary and secondary data. The results of this study conclude that in Islamic sharia, to make a living is the duty of the husband. The wife's only obligation is as a housewife who educates children and serves her husband. But it is not forbidden when the wife helps find a living for the family. According to an interviewee at the interview, stated that they women do their activities as traders is to belp their husbands in meeting family needs, as well as channeling the bobby of trade that has been buried because only become bousewives. This research also provides understanding to women in order to know their rights and obligations in the household, the urgency of how Muslim women who should carry out their daily activities become housewives as well as traders in accordance with the recommendations in their Islamic Syariah.
\end{abstract}

Keywords: Women, Families, Prosperity, Economic, Islamic

\begin{abstract}
Abstrak
Seiring berkembangnya zaman tentunya kebutuhan masyarakat meningkat dari tahun ke tahun.Kebutuhan manusia yang tidak terbatas, dengan ketersediaan sumber daya yang terbatas.Membuat para perempuan juga ikut berperan dalam pemenuhan kebutuhan keluarga guna upaya mewujudkan keluarga sejahtera.Penelitian ini dilakukan guna memberikan gambaran bagaimana peran perempuan dalam mewujudkan keluarga sejahtera ditinjau dari perspektif ekonomi Islam.Penelitian yang di lakukan di Simpang Tugu Tigo Baleh, Kelurahan Pakan Labuah, Kota Bukittinggi ini menggunakan pendekatan deskriptif kualitatif dengan data yang diperoleh dari data primer maupun sekunder.Hasil dari penelitian ini menyimpulkan bahwa dalam syari'at Islam, untuk mencari nafkah itu merupakan tugas suami.Kewajiban istri hanyalah sebagai ibu rumah tangga yang mendidik anak dan melayani suami.Namun tidaklah menjadi terlarang ketika istri ikut membantu mencarikan nafkah untuk keluarga.Menurut narasumber yang di wanwancarai, menyebutkan bahwa mereka kaum perempuan melakukan aktivitasnya sebagai pedagang adalah untuk membantu suami dalam memenuhi kebutuhan keluarga, sekaligus menyalurkan hobi berdagang yang selama ini terpendam karena hanya menjadi ibu rumah tangga.Penelitian ini juga memberikan pemahaman kepada kaum perempuan agar mengetahui hak dan kewajibannya dalam rumah tangga, urgensi tentang bagaimana seharusnya perempuan muslim yang melakukan aktivitas kesehariannya menjadi ibu rumah tangga sekaligus sebagai pedagang yang sesuai dengananjuran dalam syariat Islamnya.
\end{abstract}

Kata Kunci: Perempuan, Keluarga, Sejahtera, Ekonomi, Islam 


\section{Pendahuluan}

Kota Bukittinggi merupakan kota yang asal muasal penduduknya bersuku minangkabau. Kebiasaan orang yang bersuku minangkabau, identik dengan idealismenya yang suka berdagang.Idealisme yang dimaksud adalah orang minang itu tidak suka diatur dan dikekang.

Masyarakat minangkabau juga terkenal dengan perantaunya. Kebanyakan dari perantau minang melakukan usaha berdagang. Baik itu sebagai pedagang rumah makan yang terkenal dengan nasi padang, ataupun pedagang pakaian. Terbukti bahwa memang masyarakat minangkabau yang hobi berdagang dengan melihat jumlah pedagang pakaian di tanah abang yang berkisar sebesar 60\% pedagang pakaian adalah orang minang.Begitupun dengan rumah makannya yang di identikan dengan masakan minang dan terkenal dengan istilah “nasi padang”.Sehingga dimanapun daerahnya diplosok negeri ini pastilah ada rumah makan Padang.Begitulah kebiasaan masyarakat minang yang sudah membudaya sejak dahulunya.

Mengacu pada falsafah minangkabau yaitu "Adaik Basandi Sara', Sara' Basandi Kitabullah",maka masyarakat minangkabau itu pada prinsipnya sangat patuh terhadap aturan agama Islam dan meneladani perjalanan Rasulullah.Salah satu bentuk teladan terhadap Rasulullah yang dilakukan oleh masyarakat minangkabau dalam hal ekonomi adalah menjadi pedagang. ${ }^{1}$

Perkembangan dan kemajuan zaman tentu telah kita rasakan dari tahun ke tahun.Sehingganya menyebabkan kebutuhan masyarakat semakin meningkat disetiap pergantian tahunnya.Peningkatan kebutuhan tersebut menyebabkan sulitnya masyarakat

\footnotetext{
${ }^{1}$ Dean Ridone, "Alasan Orang Minang Suka Berdagang”, www.kompasiana.com. Diakses tanggal 6 september 2016
}

untuk memenuhi kebutuhannya.Kebutuhan manusia yang tidak terbatas dengan ketersediaan sumber daya yang terbatas, menuntut perempuan turut ikut andil dalam memenuhi hal tersebut.

Peran perempuan khususnya di Simpang Tugu Tigo Baleh, Kelurahan Pakan Labuah, Kota Bukittinggi yang melakukan aktivitasnya sebagai pedagang merupakan salah satu usaha untuk memenuhi kebutuhan keluarga.

Selain itu, pedagang di Simpang Tugu Tigo Baleh mengakui bahwa:

"Kami menjadikan usaha dagang sebagai hobi sampingan dalam rangka mengatasi kejenuhan atas rutinitas sebagai ibu rumah tangga. Sehingga dengan menyalurkan hobi dan jiwa berdagang tersebut, kami bisa membantu menambah penghasilan suami.Tidak hanya itu, mereka juga mampu membeli alat-alat kecantikan sendiri dan juga membantu biaya sekolah anak tanpa harus bergantung kepada suami. ${ }^{2}$

Penelitian ini dilakukan untuk mengetahui peran perempuan dalam mewujudkan keluarga sejahtera menurut perspektuf ekonomi Islam.Dengan rumusan masalah bagaimana peran perempuan dalam mewujudkan keluarga sejahtera menurut perspektif ekonomi Islam.

\section{Kajian Penelitian Terdahulu}

Berikut penelitian terkait yang telah dihimpun yaitu:

1. Penelitian Septi Latifa Hanum tentang Peran Ibu Rumah Tangga dalam Membangun Kesejateraan Keluarga. Pendekatan yang digunakan dalam penelitian ini adalah kualitatif deskriptif. Hasil penelitian ini mengungkapkan bahwa ibu rumah tangga sangat berperan

${ }^{2}$ Loly Anggraini, Wawancara Pribadi, Selasa 17 Maret 2020 
penting dalam membangun kesejahteraan keluarga. Selain kepandaian dalam mengelola pendapatan dari suami, ibu rumah tangga mencari sambilan pekerjaan untuk membangun kesejahteraan keluarga.

2. PenelitianShafila Mardiana Bunsaman dan Budi Muhammad Taftazani tentang Peranan Perempuan dalam Meningkatkan Kesejahteraan Ekonomi Keluarga. Pendekatan yang digunakan dalam penelitian ini adalah kualitatif deskriptif. Hasil penelitian ini mengungkapkan bahwa peranan perempuan dalam penelitian tersebut dibagi atas dua, yaitu: pertama, peranan di dalam keluarga, diantaranya adalah peranan sebagai seorang ibu dan pendamping bagi suami. Kedua, sebagai pencari nafkah, artinya perempuan ikut serta bekerja untuk meningkatkan kesejahteraan ekonomi keluarga.

3. Penelitian Ramadhan Prasetya Wibawa dan Liana Vivin Wihartanti tentang Peran Perempuan Kepala Keluarga dalam Menciptakan Kesejahteraan Keluarga. Penelitian ini menggunakan pendekatan Kualitatif Deskriptif Fenomenologis. Hasil penelitian ini mengungkapkan bahwa ibu rumah tangga yang berperan sebagai kepala keluarga memiliki upayaupaya yang kuat dalam pengelolaan manajemen agar keluarga menjadi sejahtera.

Adapun yang membedakan penelitian ini dengan penelitian terkait di atas adalah pertama, setting tempat penelitian.Dimana penelitian ini dilakukan di Simpang Tugu Tigo Baleh, Kelurahan Pakan Labuah, Kota Bukittinggi.Kemudian yang kedua, pisau analisis yang digunakan pada penelitian ini adalah Ekonomi Islam.Artinya penelitian ini menempatkan perspektif Ekonomi Islam dalam memandang peran Perempuan dalam meningkatkan kesejahteraan keluarga.

\section{Metodologi Penelitian}

1. Jenis Penelitian dan Tempat Penelitian

Merujuk pada permasalahan yang akan diteliti, maka pendekatan penelitian yang digunakan ialah deskriptif kualitatif. Pendekatan ini bertujuan untuk memaparkan perilaku orang, fenomena lapangan, serta kegiatan-kegiatan tertentu secara detail dan mendalam.Adapun yang dimaksud dengan penelitian deskriptif yaitu suatu penelitian untuk menggambarkan suatu variabel yang berkenaan dengan masalah yang diteliti. ${ }^{3}$ Adapun lokasi yang dipilih untuk melakukan penelitian ini adalah Simpang Tugu Tigo Baleh, Kelurahan Pakan Labuah, Kota Bukittinggi.

2. Jenis dan Sumber Data

Data yang diperoleh merupakan data primer dan sekunder.Data primer diperoleh melalui wawancara secara langsung kepada responden.Data sekunder di peroleh dengan mengutip dari kajian terdahulu, dan buku. ${ }^{4}$

3. Teknik Pengumpulan Data

Teknik pengumpulan data yang digunakan pada penelitian ini adalah wawancara. Wawancara ini dilakukan dengan pedagang kaki lima Simpang Tugu Tigo Baleh, Kelurahan Pakan Labuah, Kota Bukittinggi. Selain itu teknik pengumpulan data lain yang digunakan adalah teknik dokumentasi.

4. Informan Penelitian

Informan Penelitian merupakan subjek yang dapat memahami informasi dari objek sebuah penelitian.Informan penelitian ini dipilih dengan metode purposive sampling. Jadi jumlah informan dalam penelitian ini adalah sebanyak 5 orang Pedagang Kaki Lima di Simpang Tugu Tigo Baleh, Kelurahan Pakan Labuah, Kota Bukittinggi.

\section{Landasan Teori}

\section{Konsep Ekonomi Islam}

3 Sanapiah Faisal, (2015),Format -format Penelitian Sosial,Jakarta: Rajawali Press, hal. 18

4 Wiratama Suwarweni, (2014), Metodologi Penelitian Lengkap, Praktis dan Mudah Dipahami, Yogyakarta: Pustaka Baru Perss, h.73 
Manusia dituntut untuk mengelola sumber daya yang dimilikinya dengan baik karena Islam sangat menghargai konsep kepemilikan pribadi. Pengelolaan atas sumber daya harus dibangun di atas pondasi keyakinan bahwa Allah SWT merupakan pemilik atas semua sumber daya yang ada dan manusia hanya diberi amanah.

Jadi dalam pengelolaan sumber daya harus mengedepankan prinsip adil dengan tujuan agar tercapai kesejahteraan bagi manusia itu sendiri.Kesejahteraan itu tidaklah tercapai jika prinsip adil dan persaudaraan tidak diaplikasikan. Karena persaudaraandan adil adalah konsekuensi logis dari komitmen keimanan di dalam Islam.

Berbicara tentang Ekonomi Islam, bukanlah hal yang baru karena Ekonomi Islam telah ada sejak Islam itu diturunkan. Bahkan banyak para pemikir Ekonomi Islam menyakini bahwa Ekonomi Islam bukanlah sebuah disiplin ilmu melainkan bahagian dari Islam itu Sendiri. Islam sebagai ajaran hidup memberikan sejumlah petunjuk atas manusia baik itu ibadah maupun muamalah.

Berangkat dari hal di atas maka Ekonomi Islam dapat dipahami sebagai cabang ilmu pengetahuan yang bertujuan untuk menganalisis persoalan Ekonomi sehingga persoalan tersebut dapat diselesaikan dengan menjunjung tinggi ajaran Islam. ${ }^{5}$

\section{Karakteristik Ekonomi Islam}

Rozalinda dalam bukunya "Ekonomi Islam: Teori dan Aplikasi pada Aktivitas Ekonomi”, mengunakan rumusan alQaradhawi dalam mendefinisikan Ekonomi Islam. Menurut beliau Ekonomi Islam dibangun oleh asas ketuhanan, asas

5 Zuwardi, Pemikiran Ekonomi Sosialis Tan Malaka Dalam Perspektif Ekonomi Islam, Jurnal Imara, Vol. 1, No. 1, Desember 2017, h.19-20 wawasan kemanusian, akhlak dan ekonomi pertengahan. Berikut penjelasan alQaradhawi:

a. Iqtishad Rabbani (Ekonomi Ketuhanan)

Ekonomi Islam merupakan ekonomi yang menjunjung tinggi nilai-nilai ketuhanan karena tujuannya adalah pencapaian ridho Allah.

b. Iqtishad Akblaqi (Ekonomi Akhlak)

Dikotomi terhadap agama dan ekonomi merupakan faktor fundamental yang membedakan antara Ekonomi Islam dengan sistem ekonomi lainnya. Dalam Islam, ekonomi dan agama tidaklah terpisahkan, karenanya setiap aktivitas ekonomi harus dijalankan di atas pondasi akhlak.

c. Iqtishad Insani (Ekonomi Kerakyatan)

Salah satu tujuan dalam kegiatan ekonomi adalah mencapai kehidupan yang lebih baik. Dalam ekonomi Islam, umat diberi ruang untuk mewujudkan hal tersebut. Tentunya dengan memegang teguh nilai-nilai ketuhanan dan humanisme dalam pemenuhan kebutuhan.

d. Iqtishad Wasathi (Ekonomi Pertengahan)

Tawazun atau Wasathimerupakan prinsip dalam ajaran Islam. Manifestasi dari sikap tawazun dalam ekonomi adalah dengan menyeimbangkan aspekaspek duni dan akhirat dalam pemenuhan kebutuhan hidup di dunia. Artinya hak terhadap aspek dunia dan akhirat dipenuhi secara adil. ${ }^{6}$

\section{Peran Perempuan Dalam Rumah Tangga}

Pembagian peran dalam rumah tangga atas laki-laki dan perempuan merupakan budaya yang telah mengakar di Indonesia. Pembagian peran adalah konsekuensi logis dari perbedaan antara

\footnotetext{
${ }^{6}$ Rozalinda, (2014), Ekonomi Islam: Teori dan Aplikasinya pada Aktivitas Ekonomi, h. 10-11
} 
laki-laki dan perempuan dalam fungsi reproduksi. Berikut peran perempuan ditinjau dari perspektif kerjanya pada sektor domestik maupun publik:

a. Peran Tradisi yakni hanya memposisikan perempuan sebagai fungsi reproduksi. Artinya perempuan hanya bertugas di rumah saja sedangkan laki-laki mencari nafkah di luar rumah.

b. Peran Transisi yakni mengakomodir aspirasi gender, namun urusan rumah tangga tetap menjadi tanggung jawab perempuan.

c. Dwiperan memposisikan perempuan dalam kehidupan dua dunia, yaitu menempatkan peran domestik dan publik dalam posisi sama penting. Dukungan moral suami pemicu ketegaran atau sebaliknya keengganan suami akan memicu keresahan atau bahkan menimbulkan konflik terbuka atau terpendam.

d. Peran egalitarian menyita waktu dan perhatian perempuan untuk kegiatan di luar. Dukungan moral dan tingkat kepedulian lelaki sangat hakiki untuk menghindari konflik kepentingan pemilahan dan pendistribusian peranan. Jika tidak, yang terjadi adalah masingmasing akan saling berargumentasi untuk mencari pembenaran atau menumbuhkan ketidaknyamanan suasana kehidupan berkeluarga.

e. Peran kontemporer adalah dampak pilihan perempuan untuk mandiri dalam kesendirian. Jumlahnya belum banyak. Akan tetapi benturan demi benturan dari dominasi lelaki atas perempuan yang belum terlalu peduli pada kepentingan perempuan mungkin akan meningkatkan populasinya. $^{7}$

${ }^{7}$ Indah Ahdiah, Peran-Peran Perempuan Dalam Masyarakat,Jurnal Academia Fisip Untad, Vol.05, No. 02, Oktober 2013, h.3-4
Islamadalah agama yang menganut nilai-nilai egalitarian, artinya posisi laki-laki dan perempuan adalah sama dihadapan Tuhan. Kendati Islam menjunjung tinggi kesetaraan gender, namun dalam tataran praksisnya pada negara-negara Islam maupun di negara yang mayoritas Islam, masih terjadi kesenjangan gender. Hal ini terjadi bukan karena ajaran agama, melainkan faktor lain seperti kebijakan publik. Kemudian adanyafaktor kultural, norma sosial, minimya kesadaran, pendidikan, dan kemiskinan sehingga terjadi kesenjangan gender. ${ }^{8}$

Setiap manusia Allah jamin rezekinya dalam kehidupan karena Allah telah menetapkan rezeki bagi setiap orang. Jadi untuk meraih rezeki yang Allah berikan tentu manusia harus berikhtiar dalam memperolehnya. Ikhtiar manusia itu tentu dengan bekerja. Dengan begitu manusia memperoleh gaji atau pendapatan. Pendapatan inilah yang digunakan oleh manusia untuk memenuhi kebutuhan hidupnya.

Ada dua bentuk kerja yang dapat dilakukan manusia yakni pengusaha atau karyawan. Dalam melakukan pekerjaannya itu manusia dituntut untuk memberikan kemampuan terbaik yang dimilki dengan mengedepankan aspek keihklasan dan kejujuran sehingga rezeki yang diperoleh menjadi berkah. Berkah amatlah penting, karena ketentraman dan kedamaian hidup tak akan tercapai tanpa adanya keberkahan.

Manusia dalam mencari rezeki dituntut untuk tidak melupakan ibadah. Karena ibadah merupakan sarana bagi manusia untuk mendekatkan diri kepada Allah. Mendekatkan diri kepada Allah adalah wujud rasa syukur manusia atas rezeki yang selama ini diberikan. Allah SWT sama

8 Sindung Haryanto, 2015, Sosiologi Agama Dari Klasik Hingga Postmodern, Yogyakarta: Ar-Ruzz Media, h. 108-109 
sekali tidak membutuhkan rezeki apapun dari manusia, akan tetapi Allah SWT lah yang memberikan rezeki kepada manusia. Hal ini dijelaskan Allah dalam surat AdzZariyat ayat 56-58:

56. Aku tidak menciptakan jin dan
manusia melainkan agar mereka
beribadah kepada-Ku. 57. Aku tidak
menghendaki rezeki sedikitpun dari
mereka dan aku tidak menghendaki agar
mereka memberi makan kepada-Ku. 58.
Sunggub Allah, Dia-lah Pemberi rezeki
yang memiliki kekuatan lagi sangat
kokoh.

Maksud dari penjabaran materi ini adalah usaha yang dapat dilakukan dengan cara bekerja, bekerja dengan cara berdagang. Melakukan usaha dalam bentuk menawarkan suatu produk ataupun jasa untuk di jual. Hasil dari penjualan itulah yang akan di pergunakan untuk memenuhi kebutuhan sehari-hari. Untuk memperoleh pendapatan tersebut dalam ajaran Islam, tentulah harus dengan cara yang halal. Bagaimana pun sulitnya mencari rezeki dengan cara yang halal. Bersyukur atas apa yang telah dieroleh merupakan sesuatu yang di sukai oleh Allah SWT. Berikut ayat AlQur'an yang menjelaskan tentang bolehnya melakukan jual beli dengan cara yang halal Al-Baqarah Ayat 276:

"Padahal Allah telah menghalalkan jual beli dan mengharamkan riba".

Maksud dari ayat ini ialah, segala bentuk jual beli itu halal, kecuali riba.Dan ada beberapa bentuk jual beli lainnya yang di larang dalam Islam. Karena tidak sesuai dengan prinsip ekonomi Islam yang salah satuya yaitu mendatang kan maslahah atau membawa berkah. Setiap usaha yang mengandung unsur kedzaliman dan mengambil hak orang lain dengan jalan yang batil, seperti mengurangi takaran atau timbangan. Memperoleh sesuatu yang tidak diimbangi dengan kerja atau pengorbanan yang setimpal seperti riba yang juga telah dilarang pada ayat diatas, harta yang dihasilkan dari barang haram semisal khamar, bekerja di bidang yang tidak dibenarkan dalam syariat misal di diskotik dan bar. Semua itu diharamkan oleh agama
Islam untuk dilakukan. Karena hanya melakukan usaha halal lagi baiklah yang akan diridhoi oleh Allah SWT.'

Menurut Sutrisno, "ada dua faktor yang menjadi alasan bagi manusia dalam bekerja yaitu faktor instrinsik (dalam diri) dan ekstrinsik (luar diri)". ${ }^{10}$

Adapun faktor yang timbul dari dalam diri manusia adalah:

a. Keinginan untuk hidup

b. Keinginan untuk memperoleh sesuatu

c. Penghargaan

d. Pengakuan

e. Keinginan untuk menguasai sesuatu

Sedangkan faktor yang timbul dari luar diri manusia adalah:

a. Faktor lingkungan kerja

b. Kompensasi

c. Jaminan ataspekerjaan

d. Status dan tanggung jawab

Bekerja dapat dipahami sebagai aktivitas dalam memenuhi kebutuhan hidup dengan penghasilan yang diperoleh. Bahkan dalam Islam bekerja adalah ibadah selama didasari oleh niat karena Allah. Sehingga bekerja dikategorikan sebagai perbuatan yang mulia.Ada hikmah yang menarik dari Rasulullah Shallallahu 'Alaihi wa Sallam tentang urgensi bekerja, yaitu bekerja bukanlah sekedar menunaikan urusan perut belaka melainkan upaya untuk menjaga harga diridan martabat kemanusiaan itu sendiri. Oleh karena itu Islam begitu menghargai orang yang bekerja dengan tangannya sendiri.. Hal ini Allah sampaikan dalam surat At-Taubah ayat 105:

"Dan katakanlah, "bekerjalah kamu maka Allah akan melihat pekerjaanmu, begitu juga Rasul-Nya dan orang-orang mukmin, dan kamu akan dikembalikan kepada (Allah) Yang Mengetahui yang gaib dan yang nyata, lalu DiberitakanNya kepada kamu apa yang telah kamu kerjakan."

9 Rozalinda, (2014), Ekonomi Islam: Teori dan Aplikasinya pada Aktivitas Ekonomi, Jakarta: PT. Raja Grafindo Persada, h. 128-129

${ }^{10}$ Sutrisno dan Edy, (2009), Manajemen Sumber Daya Manusia, Jakarta: Kencana Edisi Pertama, Cetakan Pertama, h.124-129 


\section{Tanggung Jawab Keluarga Dalam Mencari Nafkah}

Nafkah merupakan kewajiban yang harus ditunaikan oleh suami kepada isteri sesuai dengan ketentuan dalam AlQur'an, sunnah, dan Ijma'. Adapun landasan atas wajibnya memberi nafkan sebagai mana yang terdapat dalam AlQur'an surah Al-Baqarah Ayat 233 adalah:

"Dan kewajiban ayah memberi Makan dan pakaian kepada Para ibu dengan cara ma'ruf. seseorang tidak dibebani melainkan menurut kadar kesanggupannya."

Ayat di atas menegaskan bahwa kewajiban ayah memberi makan, pakaian kepada ibu dengan cara makruf, dan itu dilakukan sesuai dengan kesanggupan. Selanjutnya ayat lain lebih menegaskan Al-Qur'an Surah AthThalaaq ayat 7 :

"Hendaklah orang yang mampu
memberi nafkah menurut
kemampuannya.dan orang yang
disempitkan rezkinya bendaklab
memberi nafkah dari harta yang
diberikan Allah kepadanya. Allah
tidak memikulkan beban kepada
seseorang melainkan sekedar apa yang
Allab berikan kepadanya. Allah kelak
akan memberikan kelapangan sesudab
kesempitan".

Telah dijelaskan melalui ayat diatas bahwa memang merupakan tanggung jawab suamilah yang menafkahi keluarga, istri, dan anak. Nafkah yang diberikan kepada keluarga tentunya Islam mengajarkan mencari nafkah dengan carama'ruf. Apabila istri melakukan aktivitas usaha untuk mendapatkan penghasilan.Itu merupkan penghasilan untuk dirinya pribadi.Kewajiban suami menafkahi isteri timbul sejak terlaksananya akad sah pernikahan antara dirinya dan isterinya itu.Kewajiban menafkahi tetap berlaku sekalipun si isteri adalah seorang perempuan kaya atau punya penghasilan sendiri. ${ }^{11}$

\section{Keluarga Sejahtera Perspektif Ekonomi Islam}

Falah merupakan term yang dipakai oleh agama dalam mendeskripsikan keadaan hidup yang sejahtera baik itu secara material maupun spiritual untuk menata kehidupan dunia dan akhirat. Falah secara sederhana adalah kemuliaan dan kemenangan dalam hidup. Falah dapat terwujud apabila pinsip persaudaraan dan keadilan $m$ sebagai realisasi dari kebutuhan materi dan rohani yang seimbang dari personalitas manusia. Karena itu,memaksimumkan output total sematamata tidak dapat menjadi tujuan dari sebuah masyarakat muslim. Memaksimalkan output, harus dibarengi dengan menjamin usaha-usaha yang ditujukan kepada kesehatan rohani yang terletak pada batin manusia, keadilan, serta permainan yang adil pada semua tingkat interaksi manusia. ${ }^{12}$

Konsep kesejahteraan dalam ekonomiIslam tidak hanya diukur berdasarkan nilai ekonomi saja, tetapi juga mencakup nilai moral, spiritual, dan juga nilai sosial. Sehingga kesejahteraan berdasarkan Islam mempunyai konsep yang lebih mendalam. ${ }^{13}$

Kemudian keluarga sejahtera ditinjau dari persfektif Undang-Undang Nomor 10 Tahun 1992 adalah keluarga yang dibentuk dari perkawinan yang sah, pemenuhan kebutuhan baik itu spiritual maupun

11 Jumni Nelli,Kewajiban Nafkah Keluarga Dalam Pemberlakuan Harta Bersama, Al Istinbath : Jurnal Hukum Islam Vol. 2, No. 1, 2017, h. 32-34

12 Martini Dwi Pusparini, (2015), “Konsep Kesejabteraan dalam Ekonomi Islam",Islamic Economics Journal, Vol.1 No.1, h.49

13 Ziauddin Sardar, (2016), "Kesejabteraan dalam Perspektif Islam pada Karyawan Bank Syariab", Jurnal Ekonomi Syariah Teori dan Terapan, Vol. 3, No. 5, h. 395 
material, religius, serasi dan selaras antara anggota dan antar anggota keluarga dengan masyarakat dan lingkungan. ${ }^{14}$

Selanjutnya ada juga Undang-Undang Nomor 52 Tahun 2009 tentang perkembangan kependudukan dan pembangunan keluarga. Hal ini tercantum pada Pasal 1 ayat 11 mendefinisikan kesejahteraan keluarga sebagai keluarga yangmencapai kehdiupan harmonis dalam meningkatkan kesejahteraan kebahagiaan lahir dan batin. ${ }^{15}$

Menurut P3EI, kesejahteraan menurut Islam mencakup dua pengertian, yaitu:

a. Kesejahteraan holistik dan seimbang, yaitu kecukupan materi yang didukung oleh terpenuhinya kebutuhan spiritual serta mencakup individu dan sosial. Sosok manusia terdiri atas unsur fisik dan jiwa, karenanya kebahagiaan haruslah menyeluruh dan seimbang diantara keduanya. Demikian pula manusia memiliki dimensi individual sekaligus sosial. Manusia akan merasa bahagia jika terdapat keseimbangan diantara dirinya dan lingkungan sosialnya.

b. Kesejahteraan secara duniawi dan ukhrawi. Sebab manusia pada dasarnya tidak hanya hidup di dunia saja. Kehidupan dunia hanya sementara. Oleh karena itu, manusia juga dituntut untuk mempersiapkan kebutuhannya kelak di akhirat. Pada dasarnya upaya pemenuhan kebtuhan di dunia adalah prasyarat dari kecukupan kebutuhan di akhirat. Amatlah merugi manusia apabila kondisi ideal dari terpenuhi kebutuhan dunia dan akhirat tidak terpenuhi. Karena terpenuhinya

${ }^{14}$ Faturochman Dan Agus Dwiyanto, (1998), "Vlidasi dan Reliabilitas Pengukuran Keluarga Sejabtera" Jurnal Populasi, Vol. 9, No. 1, h.38.

15 Marlina Telaumbanua dan Mutiara Nugraheni, (2018), "The Role of Housewives Their Family's Welfare Marietta", Sosio Informa, Vol. 4, No. 2, h. 425 kebutuhan akhirat lebih bernilai ketimbang dunia. ${ }^{16}$

Ekonomi Islam memandang kesejahteraan haruslah komprehensif. Hal ini dimaksudkan untuk pemenuhan kesejahteraan manusia mencakup aspek material maupun spiritual. Oleh karena itu, kesejahteraan tidak hanya dilihat dari nilai ekonomi saja, tetapi juga nilai moral, spiritual, dan nilai sosial. Sehingga kesejahteraan dalam tinjauanIslam lebih komprehensif.

Secara realitas, kesejahteraan hidup manusia memiliki banyak indikator. Dalam perjalanan sejarah, dari waktu ke waktu tolak ukur dari kesejahteraan senantiasa berubah. Berikut perubahannya dari waktu ke waktu:

a. Pada tahun 50-an misalnya, kesejahteraan hanya diukur dari aspek fisik seperti berat badan, tinggi, gizi, harapan hidup serta pemasukan.

b. Pada tahun 80-an ukuran dari kesejahteraan kembali berubah. Ukurannya adalah pemasukan, tenaga kerja dan hak sipil.

c. Pada tahun 90-anMahbub Ul-Haq merekonstruksi ukuran kesejahteraan denganHuman Development Index (HDI). melalui HDI, kesejahteraan tidak hanya sebatas aspek ekonomi saja, melainkan aspek kualitas sosial individu. Jadi HDI adalah gabungan dari indeks harapan hidup, indeks pendidikan, dan indeks pendapatan per kapita.

Adapun indikator kesejahteraan menurut tinjauan ekonomi konvensional didasarkan atas multi sudut pandang (Hakim2013). Berikut pandangannya:

a. Ada empat prinsip ekonomi dasar yang harus dipenuhi agar kesejahteraan

16 Pusat Pengkajian dan Pengembangan Ekonomi Islam,2008,Ekonomi Islam, Jakarta: PT. Raja Grafindo Persada, h.4 
rakyat terwujud menurut Adam Smith, dalam buku "The Wealth of Nation":

1) Prinsip keseimbangan produksi dan konsumsi;

2) Prinsip manajemen tenaga kerja;

3) Prinsip manajemen kapital;

4) Prinsip kedaulatan ada di tangan rakyat. $^{17}$

b. Menurut Miles, terdapat empat indikator yang digunkan untuk mengetahui kesejahteraan suatu keluarga, yaitu :

1) Rasa aman (security)

2) Kebebasan (freedom)

3) Kesejahteraan (welfare)

4) Jati diri (identity) ${ }^{18}$

Menurut beberapa ahli dalam buku P3EI, "indikator kesejahteraan hidup menurut Islam adalah terwujudnyakebutuhan fisik dari rizqi yang halal, hidup sehat secara jasmani dan rohani, keberkahan rezeqi yang diterima, keluarga yang sakinah mawaddah wa rahmah, rasa cinta kasih sesama, ridha dan qana'ah dengan apa yang diberikan Allah kepadanya serta merasa bahagia". Artinya kesejahteraan dalam Islam memiliki multi dimensi yakni material dan. ${ }^{19}$

a. Ad-dien: Memelihara agama.

Ryandono mengatakan bahwa indikator dari memelihara agama adalah terlaksananya rukun Islam seperti syahadat, shalat, puasa, zakat dan haji serta komitmen dengan rukun iman.

b. An-nafs: Memelihara Jiwa.Hal ini terwujud jika kebutuhan sandang, pangan, tempat tinggal, kesehatan,

${ }^{17}$ Abdul, Hakim,2013,Pengarub Dana Bantuan Langsung Masyarakat Terbadap Penyerapan Tenaga Kerjadan Perkembangan Usaba Tani Padi Serta Kesejabteraan Keluarga Petani Kabupaten Kota di Provinsi Nusa Tenggara Barat Dalam Perspektif Islam,Disertasi tidak diterbitkan, Pascasarjana Universitas Airlangga, h. 26

18 Miles,(1985),Social Indicator for Human Development,From Printer Publicers. h. 15

${ }^{19}$ Qardawi dan Yusuf, (2008), Halal dan haram, serta fasilitas umum lainnya terpenuhi. ${ }^{20}$

c. Al-aql: Memelihara Akal. Menurut AlSyatibhi dalam Bakri memelihara akal dibagi atas tiga peringkat yaitudharuriyah seperti diharamkannya meminum minuman keras. Kemudian hajjiyah sepertianjuran menuntut ilmu pengetahuan. Selanjutnya tahsiniyyah seperti menghindarkan diri dari mendengarkan sesuatu yang tidak bermanfaat.

d. An-nasl: Memelihara Keturunan. Kita sebagai manusia tidak perlu khawatir apabila masih belum mampu dalam hal ekonomi untuk menikah karena Allah SWT akan memberikan rezeki serta karunia-Nya. ${ }^{21}$

e. Al-maal: Memelihara Harta. Menurut Ryandono, "cara menjaga harta adalah meliputi mencari pendapatan yang layak dan adil, memiliki kesempatan berusaha, rejeki yang halal dan thoyib, serta persaingan yang adil". ${ }^{22}$

\section{Pengertian Pedagang Kaki Lima}

Pedagang adalah mereka yang melakukan perbuatan perniagaan (perdagangan) sebagai pekerjaannya seharihari. ${ }^{23}$ Pedagang kaki lima merupakanpedagang atau orang yang melakukan kegiatan atau usaha kecil tanpa didasari atas ijin dan menempati pinggiran jalan (trotoar) untuk menggelar dagangan. Menurut Evens dan Korff, "Definisi pedagang kaki lima adalah bagian dari

20 Ryandono dan Muhammad Nafik Hadi, (2008),Ekonomi ZISWAQ (Zakat, Infaq,Shadaqah dan Waqaf). Surabaya: IFDI dan Cenforis, h.30

${ }^{21}$ Bakri dan Asafri Jaya,(1997). Konsep Maqashid Syariah menurut al-Syatibi, Jakarta: Logos wacana, h.28

${ }^{22}$ Ryandono dan Muhammad Nafik Hadi, (2008), Ekonomi ZISW AQ, h.30

23 Purwosutjipto, 1999,Pengertian Pokok Hukum Dagang Indonesia: Pengetahuan Dasar Hukum Dagang, Jakarta: Djambatan, h.10 
sektor informal kota yang yangmengembangkan aktivitas produksi barang dan jasa di luar kontrol pemerintah dan tidak terdaftar". ${ }^{24}$

\section{Hasil dan Pembahasan}

1. Jenis Kelamin Responden (Pedagang Kaki Lima Simpang Tugu Tigo Baleh,

Kelurahan Pakan Labuah, Kota
Bukittinggi)

Dewasa ini perempuan dianggap memiliki hak dan kesempatan yang sama halnya dengan laki-laki. Berbeda dengan zaman dulu yang tidak memperbolehkan perempuan bekerja dan perempuan hanya diperbolehkan berada didalam rumah sekarang ini banyak sekali perempuan yang memiliki peran ganda dalam keluarga, tidak hanya terfokus pada tugasnya di dalam rumah tangga mereka pun diperbolehkan untuk bekerja sama halnya dengan laki-laki. Biasanya para perempuan bekerja karena penghasilan suami tidak mencukupi untuk memenuhi kebutuhan keluarga atau pun karena mereka ingin membantu suami dalam meningkatkan kesejahteraan keluarga. Data jenis kelamin responden pedagang kaki lima di Simpang Tugu Tigo Baleh, Kelurahan Pakan Labuah, Kota Bukittinggi.

Tabel 1 Jenis Kelamin Pedagang Kaki Lima Simpang Tugu Tigo Baleh, Kelurahan Pakan Labuah, Kota Bukittinggi

\begin{tabular}{|l|c|c|}
\hline Keterangan & Frekuensi & Persentase \\
\hline Laki-Laki & 3 & $37,5 \%$ \\
\hline Perempuan & 5 & $62,5 \%$ \\
\hline Jumlah & 8 & $100 \%$ \\
\hline
\end{tabular}

Sumber Data: Wawancara Selasa, 17 Maret 2020

24 Evers HD dan Rudiger Korff, 2002, Urbanisasi di Asia tenggara: Makna dan kekuasaan dalam ruang-ruang sosial, Jakarta: Yayasan Obor Indonesia, h. 234
Dapat dilihat dari tabel 1.1 diatas bahwa pedagang kaki lima di Simpang Tigo Baleh, Kelurahan Pakan Labuah, Kota Bukittinggi lebih di dominasi oleh perempuan dibandingkan dengan pedagang laki-laki. Para perempuan pedagang kaki lima ini memiliki alasan dan lebih memilih menjadi pedagang kaki lima ketimbang hanya menjadi ibu rumah tangga saja. Mereka bekerja untuk membantu perekonomian keluarga.Dari jumlah pedagang yang ada, penulis hanya akan mewawancarai pedagang perempuan saja, yaitu sejumlah 5 orang.

2. Umur Responden (Pedagang Kaki Lima Simpang Tugu Tigo Baleh, Kelurahan Pakan Labuah, Kota Bukittinggi)

Umur dapat dijadikan sebagai tolak ukur untuk melihat aktifitasseseorang dalam bekerja. Ketika usia masih produktif memungkinan seseorang untuk bekerja dengan baik dan maksimal.Tenaga kerja merupakan penduduk yang berada dalam usia kerja. Menurut UU No. 13 tahun 2003 Bab I pasal 1 ayat 2 disebutkan bahwa tenaga kerja adalah setiap orang yang mampu melakukan pekerjaan guna menghasilkan barang atau jasa baik untuk memenuhi kebutuhan sendiri maupun untuk masyarakat.Secara garis besar penduduk suatu negara dibedakan menjadi dua kelompok, yaitu tenaga kerja dan bukan tenaga kerja. Penduduk tergolong tenaga kerja jika penduduk tersebut telah memasuki usia kerja. Batas usia kerja yang berlaku di Indonesia adalah berumur 15 tahun - 64 tahun.

Tabel 2 Umur Perempuan Pedagang Kaki Lima di Simpang Tugu Tigo Baleh, Kelurahan Pakan Labuah, Kota Bukittinggi

\begin{tabular}{|c|c|c|}
\hline Umur & Frekuensi & Persentase \\
\hline$\leq 29$ & 2 & $40 \%$ \\
\hline
\end{tabular}




\begin{tabular}{|c|c|c|}
\hline $30-39$ & 1 & $20 \%$ \\
\hline $40-49$ & 2 & $40 \%$ \\
\hline Jumlah & 5 & $100 \%$ \\
\hline
\end{tabular}

Sumber Data: Wawancara Selasa, 17 Maret 2020

Dapat dilihat dari tabel 1.2 diatas bahwa umur dari responden perempuan pedagang kaki limaSimpang Tigo Baleh, Kelurahan Pakan Labuah, Kota Bukittinggi merupakan kategori usia produktif. Mampu melakukan aktivitas sehari-hari dengan baik.

3. Pendapatan dan Pengeluaran Responden (Pedagang Kaki Lima Simpang Tugu Tigo Baleh, Kelurahan Pakan Labuah, Kota Bukittinggi

Penghasilan keluarga sangat berpengaruh dalam kesejahteraan keluarga. Semakin tinggi penghasilan sebuah keluarga maka akan semakin tinggi pula kesempatan untuk dapat memenuhi segala kebutuhan. Data penghasilan total keluarga perbulan respondenperempuan pedagang kaki limaSimpang Tigo Baleh, Kelurahan Pakan Labuah, Kota Bukittinggi. Dapat dilihat gambarannya melalui tabel dibawah ini.

Tabel 3 Pendapatan Responden perempuan pedagang kaki lima Simpang Tigo Baleh, Kelurahan Pakan Labuah, Kota Bukittinggi

\begin{tabular}{|c|c|c|}
\hline Pendapatan & Frekuensi & Persentase \\
\hline$<$ Rp1.000.000 & 0 & $0 \%$ \\
\hline $\begin{array}{l}\text { Rp1.000.000- } \\
<\mathrm{Rp} 2.000 .000\end{array}$ & 3 & $60 \%$ \\
\hline $\begin{array}{c}\text { Rp2.000.000- } \\
<\mathrm{Rp} 3.000 .000\end{array}$ & 2 & $40 \%$ \\
\hline Jumlah & 5 & $100 \%$ \\
\hline
\end{tabular}

Sumber Data: Wawancara Selasa, 17 Maret 2020
Selain penghasilan adapun pengeluaran keluarga, pengeluaran rumah tangga dapat digunakan untuk kebutuhan sehari-hari, untuk pendidikan, untuk kesehatan dan sebagainya.Jika rata-rata pengeluaran total keluarga per bulan lebih besar dibandingkan rata-rata penghasilannya maka dapat dipastikan bahwa keluarga harus mencari uang tambahan untuk dapat memenuhi kebutuhan tersebut. Data ratarata pengeluaran total keluarga per bulan responden perempuan pedagang kaki lima di Simpang Tigo Baleh, Kelurahan Pakan Labuah, Kota Bukittinggi. Dapat dilihat gambarannya melalui tabel dibawah ini.

Tabel 4 Pengeluaran Total Keluarga per Bulan Responden Perempuan Pedagang Kaki Lima di Simpang Tigo Baleh, Kelurahan Pakan Labuah, Kota Bukittinggi

\begin{tabular}{|c|c|c|}
\hline Pengeluaran & Frekuensi & Persentase \\
\hline$<\mathrm{Rp} 1.000 .000$ & 0 & $0 \%$ \\
\hline $\begin{array}{c}\text { Rp1.000.000- } \\
<\mathrm{Rp} 2.000 .000\end{array}$ & 0 & $0 \%$ \\
\hline $\begin{array}{c}\text { Rp2.000.000- } \\
<\mathrm{Rp} 3.000 .000\end{array}$ & 3 & $60 \%$ \\
\hline$>\mathrm{Rp} 3.000 .000$ & 2 & $40 \%$ \\
\hline Jumlah & 5 & $100 \%$ \\
\hline
\end{tabular}

Sumber Data: Wawancara Selasa, 17 Maret 2020

Dari tabel 1.4 dapat dilihat bahwa pendapatan responden paling banyak antara Rp 1.000.000 - <Rp 2.000.000 dengan jumlah 3 orang atau $60 \%$. Sementara penghasilan responden paling sedikit adalah kurang dari Rp. 1.000.000 dengan jumlah 0 orang atau dengan kata lain tidak ada seorang pun responden yang memiliki pendapatan kurang dari Rp 1.000.000.

Hal ini sama halnya dengan pengeluaran, pengeluaran responden paling 
banyak adalah antara Rp $2.000 .000-<\mathrm{Rp}$ 3.000 .000 dengan jumlah 3 orang atau $60 \%$. Sedangkan pengeluaran responden paling sedikit adalah dibawah Rp 1.000.000 dengan jumlah 0 orang, atau bisa dikatakan bahwa tidak ada seorang responden pun yang memiliki pengeluaran total perbulan kurang dari Rp 1.000.000.

Dari hal tersebut diatas maka dapat disimpulkan jika beberapa responden memiliki rata-rata total pengeluaran per bulan yang lebih besar dibandingkan dengan rata-rata penghasilannya.Banyak faktor yang dapat menyebabkan hal ini terjadi, misalnya adalah beban hidup yang lebih besar dibandingkan dengan kemampuannya dalam menghasilkan pendapatan. Oleh karena itu, peran perempuan sebagai istri untuk ikut membantu suami dalam mencari nafkah tentu akan sangat berarti.

Lantas bagaimana Ekonomi Islam memandang keterlibatan perempuan dalam mewujudkan keluarga sejahtera?Kala perempuan bekerja mencari nafkah layaknya kaum laki-laki maka hal tersebut diperbolehkan dalam Islam.Karena sumbersumber Islam yang otoritatif tidak satupun yang menafikan kerja dan profesi kaum perempuan dalam bidang dan sektor apapun dalam hal mencari nafkah.Tentu mencari nafkah harus tetap berjalan di atas koridor nilai-nilai agama, artinya tidak menimbulkan fitnah dan tidak melalaikan kewajiban utama perempuan sebagai seorang ibu rumah tangga dan pendidik anak. Bahkan Islam menegaskan baik itu laki-laki maupun perempuan yang bekerja dan beramal baik akan mendapatkan kehidupan yang baik dan sejahtera. Tentu hal tersebut dapat terwujud apabila kedua pasangan itu saling tolon-menolong, saling membutuhkan, saling menjaga dan saling melengkapi.

\section{Kesimpulan}

Dari hasil penelitian ini maka dapat disimpulkan, bahwa Islam merupakan agama yang menganut egalitarian karena menganggap laki-laki dan perempuan memiliki kesempatan yang sama untuk memperoleh kedudukan yang sama dihadapan Tuhan.Peran perempuan yang di teliti adalah sebagai pedagang kaki lima. Pedagang kaki lima dalam aspek hukum bisnis tidak memiliki surat izin usaha pada pemerintah. Namun pedagang kaki lima ini boleh melakukan usahanya asal tidak mengganggu arus lalu lintas pejalan kaki maupun kendaraan bermotor.

Usaha yang dilakukan dengan cara yang halal lagi baik dan juga sesuai aturan umum dan tidak melanggarnya di perbolehkan dalam Islam. Berarti peran perempuan sebagai pedagang kaki lima boleh tidak ada larangan dalam Islam.

Perlu ditekankan bahwa menurut perspektif Islam, kewajiban mencari nafkah itu merupakan tanggung jawab suami.Namuntidaklahmenjaditerlarangketikaist riikutmembantumencarikannafkahuntukkeluar ga. Sebagai perempuan pedagang kaki lima melakukan usaha yang dapat membantu memenuhi kebutuhan keluarga merupakan perbuatan yang mulia menurut Islam. Dalam upaya mewujudkan keluarga sejahtera.Kebahagiaan dunia dan akhirat adalah orientasi hidup manusia.Seberapapun hasil yang diperoleh melalui usaha tersebut.Islam mengajarkan kita untuk selalu bersyukur dan berpikir.Berpikir untuk lebih maju kedepannya.Selalu berikhtiar dalam mewujudkan keluarga sejahtera.

Hasil dari penelitian ini juga menggambarkan usaha yang dilakukan oleh perempuan pedagang kaki lima di Simpang Tugu Tigo Baleh, Kelurahan Pakan Labuah, Kota Bukittinggi ini sudah cukup untuk membantu memenuhi kebutuhan keluarga. Walaupun masih kurang dalam memenuhi kebutuhan keluarga per bulannya. Namun dari responden yang penulis wawancarai, secara keseluruhan masih memiliki suami yang bekerja di tempat lain. jika pendapatan suami dan istri di gabungkan maka terpenuhilah kebutuhan keluarga secara keseluruhan. Terkadang keluarga dapat menabung, 
terkadang juga kekurangan dana. Begitulah hasil dari usaha yang dilakukan dengan berdagang.Pendapatannya masih belum dapat di pastikan.

\section{Daftar Pustaka}

Abdul, Hakim, (2013), Pengarub Dana Bantuan Langsung Masyarakat Terhadap Penyerapan Tenaga Kerja dan Perkembangan Usaha Tani Padi Serta Kesejahteraan Keluarga Petani Kabupaten Kota di Provinsi Nusa Tenggara Barat Dalam Perspektif Islam,Disertasi tidak diterbitkan, Pascasarjana Universitas Airlangga.

Bakri dan Asafri Jaya,(1997). Konsep Maqashid Syariah menurut al-Syatibi,Jakarta: Logos wacana.

Dean Ridone, "Alasan Orang Minang Suka Berdagang”,www.kompasiana.com.Diak ses tanggal 6 september 2016.

Evers HD dan Rudiger Korff, 2002, Urbanisasi di Asia tenggara: Makna dan kekuasaan dalam ruang-ruang sosial, Jakarta: Yayasan Obor Indonesia.

Faturochman Dan Agus Dwiyanto, (1998), "Vlidasi dan Reliabilitas Pengukuran Keluarga Sejabtera" Jurnal Populasi, Vol. 9, No. 1.

Haryanto, Sindung. Sosiologi Agama Dari Klasik Hingga Postmodern.Yogyakarta: Ar-Ruzz Media. 2015.

Indah Ahdiah, Peran-Peran Perempuan Dalam Masyarakat,Jurnal Academia Fisip Untad, Vol. 05, No. 02, Oktober 2013.

Loly Anggraini, Wawancara Pribadi, Selasa 17 Maret 2020

Marlina Telaumbanua dan Mutiara Nugraheni, (2018), "The Role of Housenvives Their Family's Welfare Marietta", Sosio Informa, Vol. 4, No. 2.

Martini Dwi Pusparini, (2015), “Konsep Kesejabteraan dalam Ekonomi Islam", Islamic Economics Journal, Vol.1 No.1.

Miles, (1985), Social Indicator for Human Development, From Printer Publicers.

Nelli Jumni, Kewajiban Nafkah Keluarga Dalam Pemberlakuan Harta Bersama, Al Istinbath: Jurnal Hukum Islam Vol. 2, No. 1, 2017.
Purwosutjipto, 1999, Pengertian Pokok Hukum Dagang Indonesia: Pengetahuan Dasar Hukum Dagang, Jakarta: Djambatan.

Pusat Pengkajian dan Pengembangan Ekonomi Islam,2008, Ekonomi Islam, Jakarta: PT. Raja Grafindo Persada.

Ramadhan Prasetya Wibawa dan Liana Vivin Wihartanti, (2018), Peran Perempuan dalam Menciptakan Kesejabteraan Keluarga. EcoSocio: Jurnal Ilmu dan Pendidikan Ekonomi-Social Vol. 2 No. 2

Rozalinda, (2014), Ekonomi Islam: Teori dan Aplikasinya pada Aktivitas Ekonomi, Jakarta: PT. Raja Grafindo Persada.

Ryandono dan Muhammad Nafik Hadi, (2008), Ekonomi ZISWAQ (Zakat, Infaq,Shadaqah dan Waqaf). Surabaya: IFDI dan Cenforis.

Sanapiah Faisal, (2015), Format-format Penelitian Sosial, Jakarta: Rajawali Press.

Septi Latifa Husna, (2017), Peeran Ibu Rumah Tangga dalam Membangun Kesejabteraan Keluarga, Academica: Journal of Multidisciplinary Studies, Vol. 1 No.2

Sutrisno dan Edy, (2009), Manajemen Sumber Daya Manusia, Jakarta: Kencana Edisi Pertama, Cetakan Pertama.

Wiratama Suwarweni, (2014), Metodologi Penelitian Lengkap, Praktis dan Mudah Dipahami, Yogyakarta: Pustaka Baru Pers.

Ziauddin Sardar, (2016), "Kesejabteraan dalam Perspektif Islam pada Karyawan Bank Syariah", Jurnal Ekonomi Syariah Teori dan Terapan, Vol. 3, No. 5.

Zuwardi, Pemikiran Ekonomi Sosialis Tan Malaka Dalam Perspektif Ekonomi Islam, Jurnal Imara, Vol. 1, No. 1, Desember 2017.

Zuwardi, KonsepProduksiMenurut Tan MalakaDitinjaudariPerspektifEkonomi Islam, Jurnal Jusie, Vol. IV, No. 2. 